Electronic Supplementary Information

\title{
Molecular Fluorescent Probe for Imaging and Evaluation of Hypochlorite Fluctuations during Diagnosis and Therapy of Osteoarthritis in Cells and in Mice Model
}

Ji-Ting Hou, $\uparrow^{\mathrm{a}, \mathrm{b}}$ Bingya Wang, $\uparrow^{\mathrm{a}}$ Yuxia Zou, $+^{\mathrm{b}}$ Peiwen Fan, ${ }^{\mathrm{a}}$ Xueping Chang, ${ }^{\mathrm{a}}$ Xinhua Cao, ${ }^{* a}$ Shan Wang *a and Fabiao $\mathrm{Yu}^{* b}$

a College of Chemistry and Chemical Engineering, Xinyang Normal University, Xinyang 464000, PR China.E-mail: caoxh@xynu.edu.cn (X.Cao); smallcoral@live.cn (S.Wang)

${ }^{b}$ Key Laboratory of Emergency and Trauma, Ministry of Education, Key Laboratory of Hainan Trauma and Disaster Rescue, The First Affiliated Hospital of Hainan Medical University, Institute of Functional Materials and Molecular Imaging, Research Unit of Island Emergency Medicine, Chinese Academy of Medical Sciences (No. 2019RU013), College of Emergency and Trauma, Hainan Medical University, Haikou 571199, China.E-mail: yufabiao@hainmc.edu.cn (F.Yu) †These authors contributed equally.

\section{Contents}

$\begin{array}{ll}\text { DFT calcultions } & \text { S2 }\end{array}$

$\begin{array}{ll}\text { Figure S1 } & \text { S3 }\end{array}$

$\begin{array}{ll}\text { Figure } \mathrm{S} 2 & \mathrm{~S} 3\end{array}$

$\begin{array}{ll}\text { Figure S3 } & \text { S4 }\end{array}$

Figure S4 $\quad$ S4

Figure S5 $\quad$ S5

Figure S6 $\quad$ S5

Figure S7

Figure S8 $\quad$ S6

$\begin{array}{ll}\text { Figure S9 } & \text { S7 }\end{array}$

$\begin{array}{ll}\text { Figure S10 } & \text { S7 }\end{array}$

Figure S11 $\quad$ S8

Figure S12 S8

Figure S13 $\quad$ S9

Figure S14 $\quad$ S9

$\begin{array}{lr}\text { NMR and MS copies of various compounds } & \text { S10 -15 }\end{array}$ 


\section{DFT calculations.}

Geometries in the $\mathrm{S}_{0}$ state were optimized using the B3LYP/6-31G* method without geometric constraints. ${ }^{1-7}$ The nature of these minima was confirmed by computing their harmonic vibrational frequencies with no image frequencies. Geometries in the $\mathrm{S}_{1}$ state were optimized using the TD-B3LYP/6-31G* method without geometric constraints. $^{1-8}$ The polarizable continuum model (PCM) was employed to implicitly account for solvent effects (water). ${ }^{9}$ The excitation energies and oscillator strengths were computed using the TD-B3LYP/6-311++G**/PCM method. ${ }^{1-9}$ All DFT calculations were carried out using the GAUSSIAN09 package. ${ }^{10}$

\section{Reference:}

1. Parr, R. G.; Yang, W. T. Density-Functional Theory of Atoms and Molecules; Oxford University Press: New York, 1994.

2. Vosko, S. H.; Wilk, L.; Nusair, M. Accurate spin-dependent electron liquid correlation energies for local spin density calculations: a critical analysis. Can. J. Phys. 1980, 58, 1200-1211.

3. Lee, C.; Yang, W. T.; Parr, R. G. Development of the Colle-Salvetti correlation-energy formula into a functional of the electron density. Phys. Rev. B: Condens. Matter Mater. Phys. 1988, 37, 785-789.

4. Becke, A. D. Density-functional exchange-energy approximation with correct asymptotic behavior. Phys. Rev. A: At., Mol., Opt. Phys. 1988, 38, 3098-3100.

5. Becke, A. D. A new mixing of Hartree-Fock and local density-functional theories. J. Chem. Phys. 1993, 98, 1372-1377.

6. Ditchfield, R.; Hehre, W. J.; Pople, J. A. Self-consistent molecular-orbital methods. ix. an extended gaussian-type basis for molecular-orbital studies of organic molecules. J. Chem. Phys. 1971, 54, 724-728.

7. Francl, M. M.; Pietro, W. J.; Hehre, W. J.; Binkley, J. S.; Gordon, M. S.; DeFrees, D. J.; Pople, J. A. Self-consistent molecular orbital methods. XXIII. A polarization-type basis set for second-row elements. J. Chem. Phys. 1982, 77, 3654-3665.

8. Marques, M. A. L.; Ullrich, C. A.; Nogueira, F.; Rubio, A.; Burke, K.; Gross, E. K. U. Eds. Time-Dependent Density Functional Theory; Springer: Berlin, Heidelberg, New York, 2006.

9. Barone, V.; Cossi, M. Quantum calculation of molecular energies and energy gradients in solution by a conductor solvent model. J. Phys. Chem. A 1998, 102, 1995-2001.

10. Frisch, M. J.; Trucks, G. W.; Schlegel, H. B.; Scuseria, G. E.; Robb, M. A.; Cheesem, J. R.; Scalmani, G.; Barone, V.; Mennucci, B.; Petersson, G. A. et al. Gaussian 09, rev. A.02; Gaussian, Inc.: Wallingford, CT, 2009. 


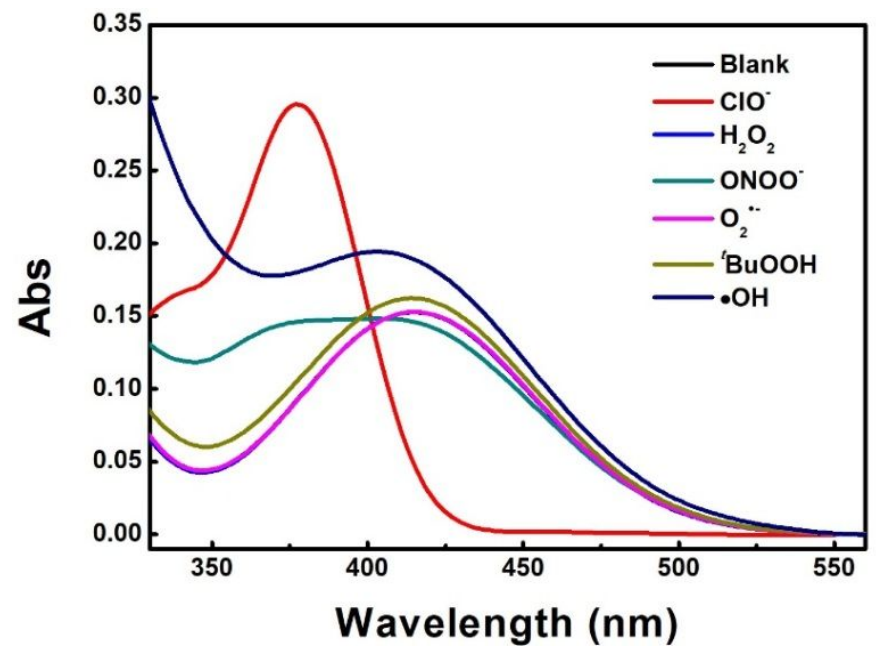

Figure S1. UV-vis absorption spectra of PDC $(10 \mu \mathrm{M})$ before and after addition of various reactive species $(100 \mu \mathrm{M})$ in PBS solution. $(\mathrm{pH} 7.2-7.4,10 \mathrm{mM})$.

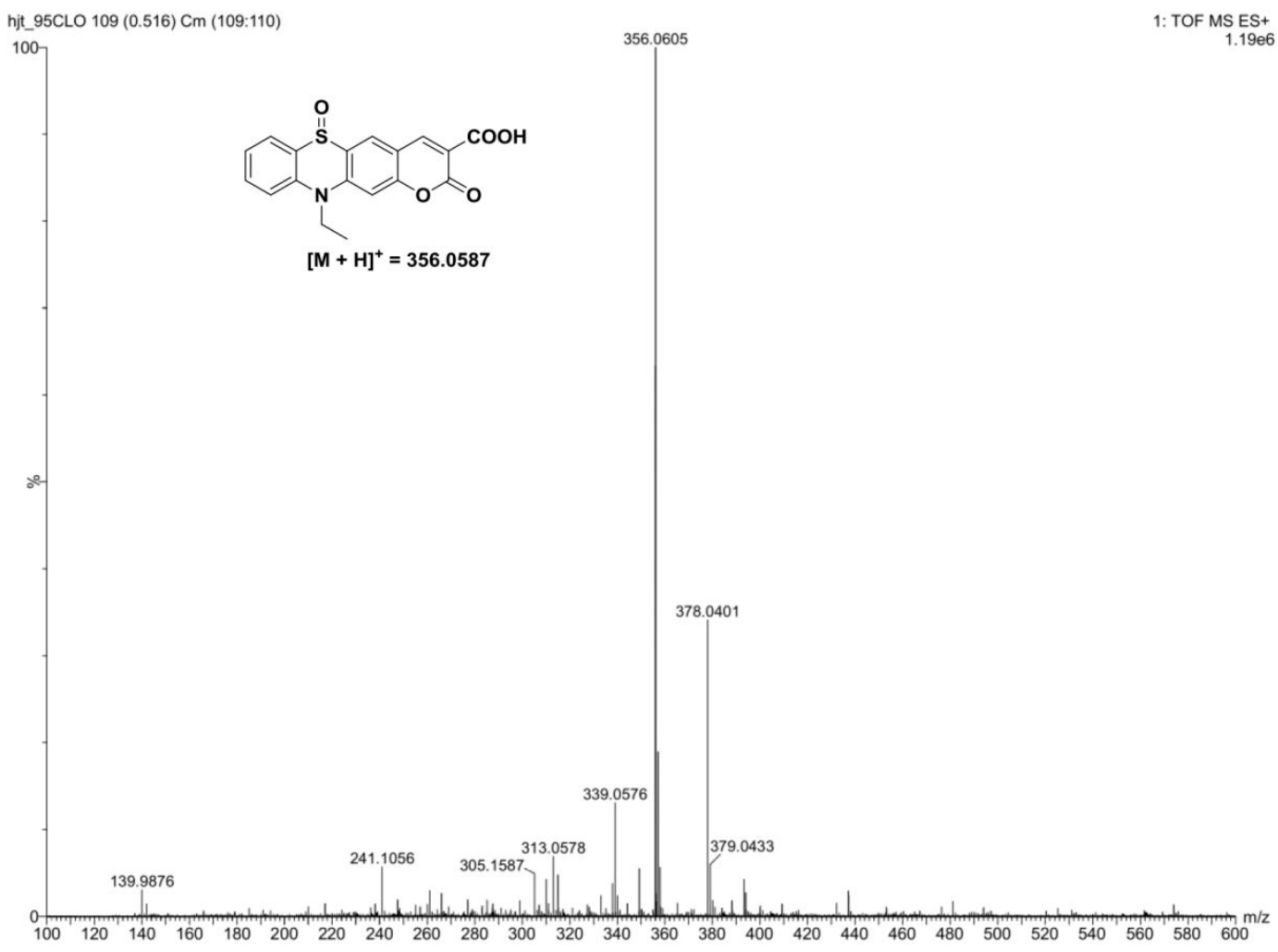

Figure S2. ESI spectra of PDC upon addition of 10 equiv. $\mathrm{NaOCl}$. 


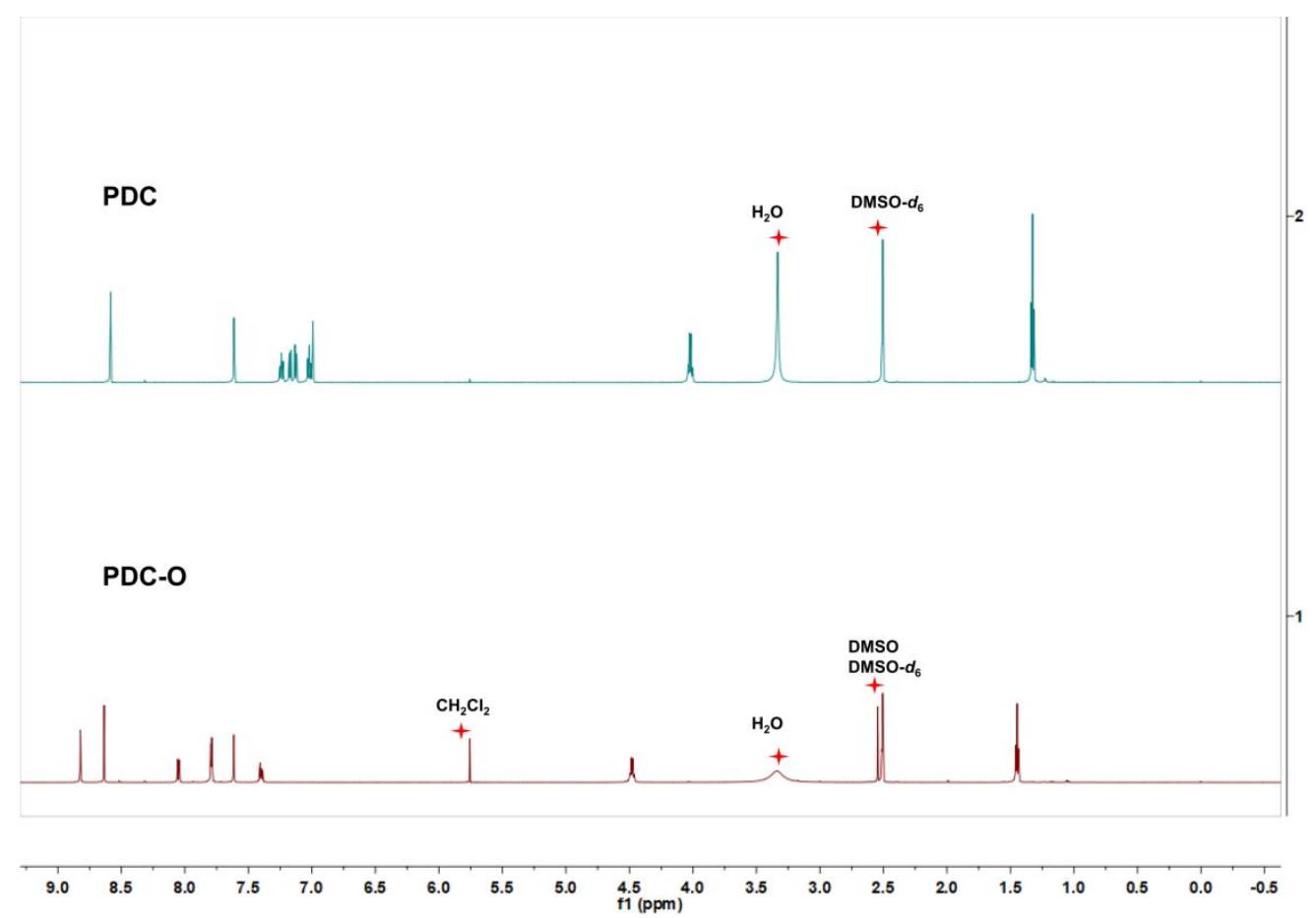

Figure S3. The comparison of the ${ }^{1} \mathrm{H}$ NMR spectra between PDC and PDC-O in DMSO- $d_{6}$.

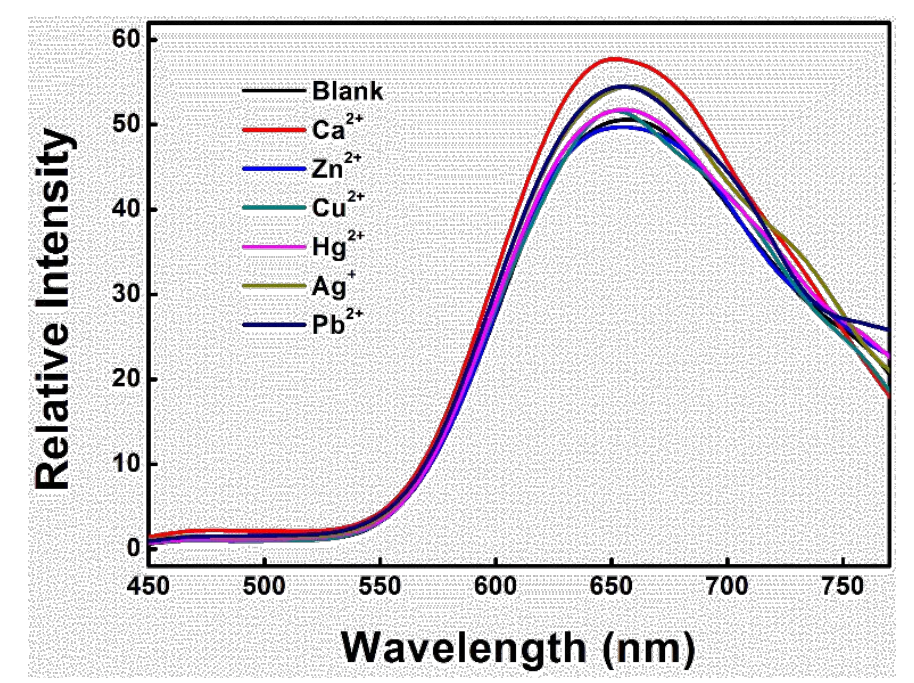

Figure S4. Emission spectra of PDC $(10 \mu \mathrm{M})$ before and after addition of various metal ions (100 $\mu \mathrm{M}$ ) in PBS solution. (pH 7.2-7.4, $10 \mathrm{mM}$ ). $\lambda_{\mathrm{ex}}=400 \mathrm{~nm}$, slit width: $5 \mathrm{~nm} / 5 \mathrm{~nm}$. 

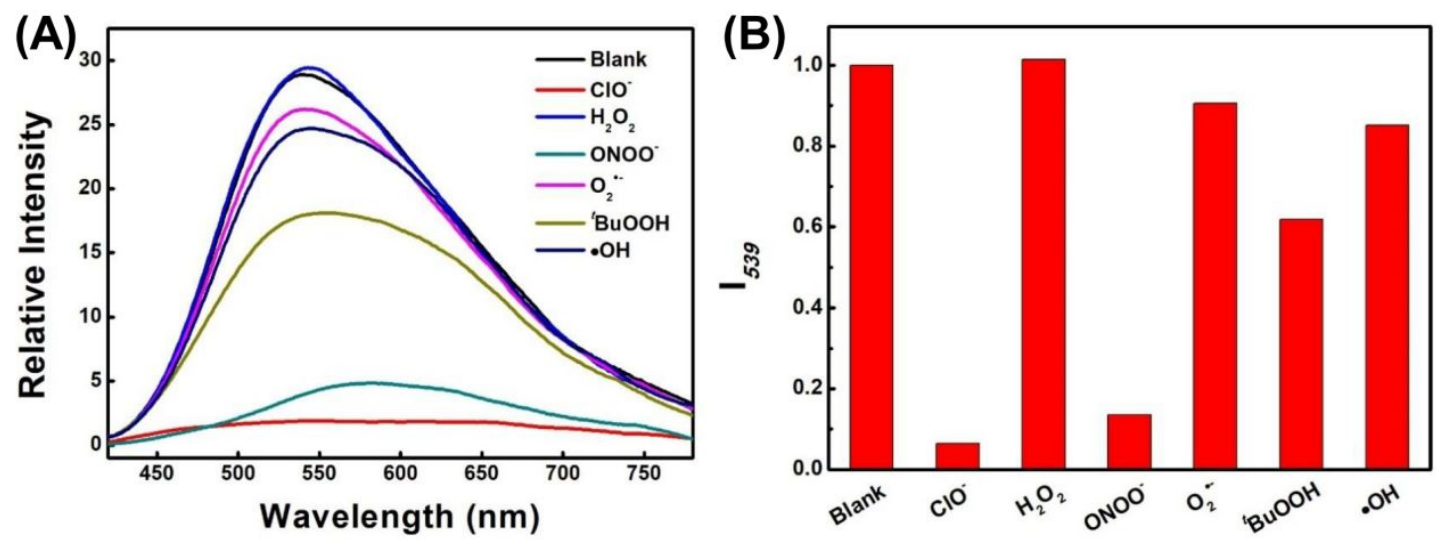

Figure S5. (a) Emission spectra of PDN $(10 \mu \mathrm{M})$ before and after addition of various reactive species $(100 \mu \mathrm{M})$ in PBS solution (pH 7.2-7.4, $10 \mathrm{mM}$, containing $20 \% \mathrm{EtOH})$. (b) The intensity changes of PDN before and after addition of various reactive species. $\lambda_{\mathrm{ex}}=400 \mathrm{~nm}, \lambda_{\mathrm{em}}=539 \mathrm{~nm}$, slit width: $6 \mathrm{~nm} / 6 \mathrm{~nm}$.
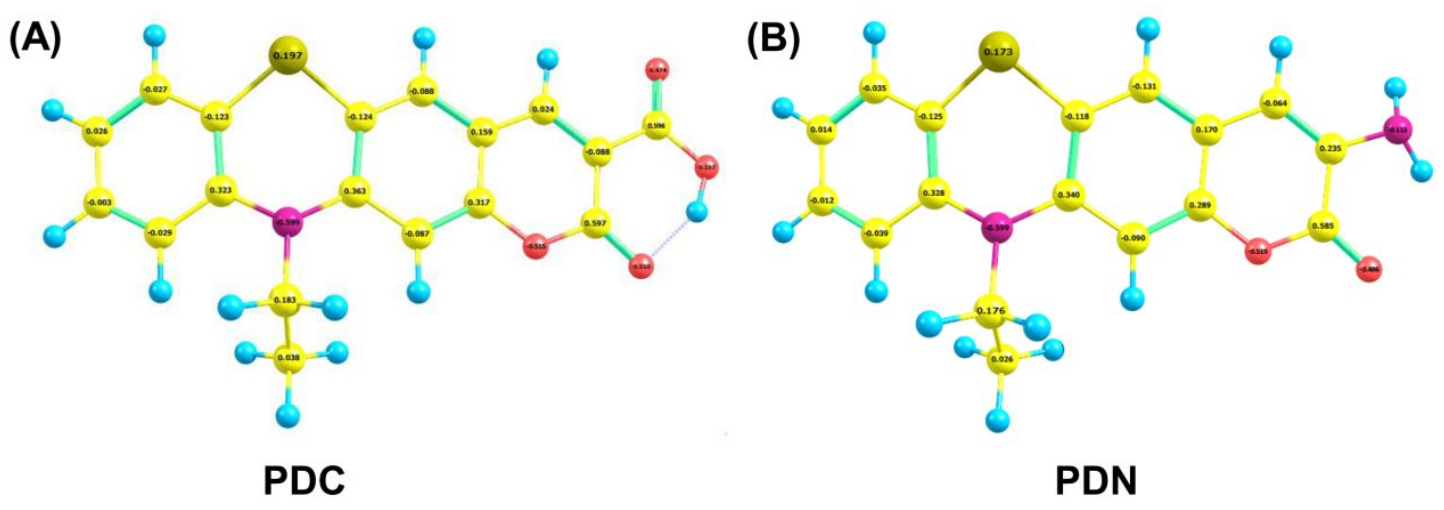

Figure S6. Structures and the mulliken charge of the optmized (A) probe PDC and (B) probe PDN at B3LYP/6-31G* level. 


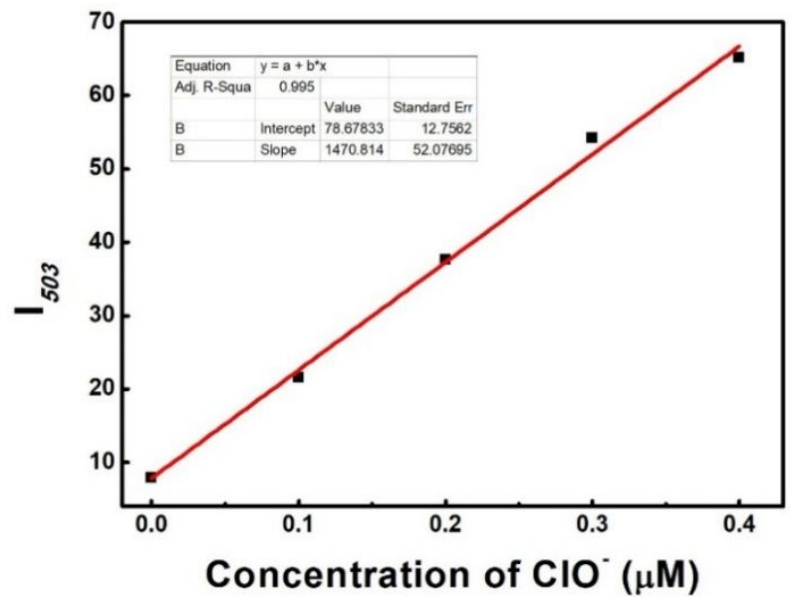

Figure S7. Linear relationship between fluorescence intensity $\left(I_{503}\right)$ of PDC $(10 \mu \mathrm{M})$ and low concentrations of $\mathrm{ClO}^{-}$.

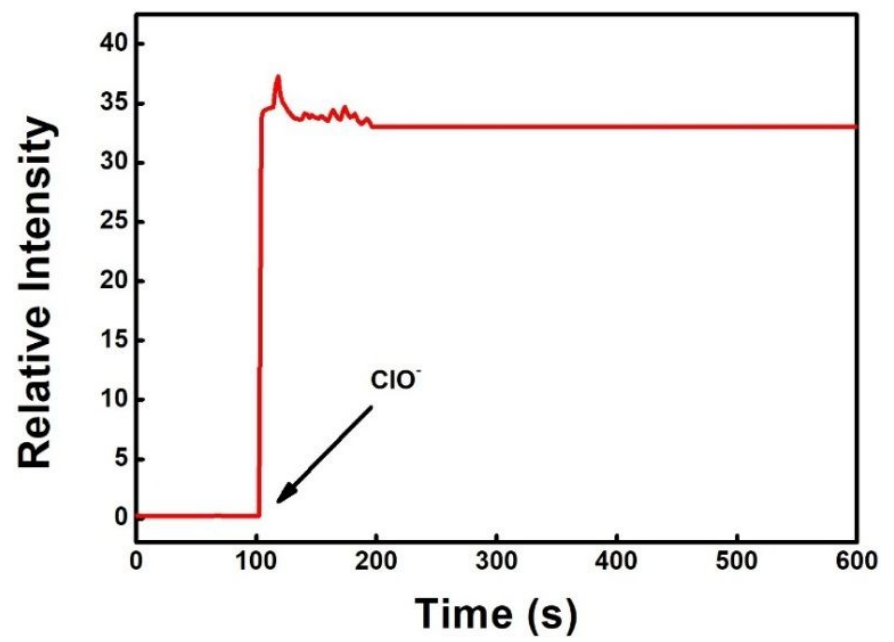

Figure S8. Time-dependent fluorescence change of PDC $(10 \mu \mathrm{M})$ at $503 \mathrm{~nm}$ to $\mathrm{ClO}^{-}(100 \mu \mathrm{M})$. 


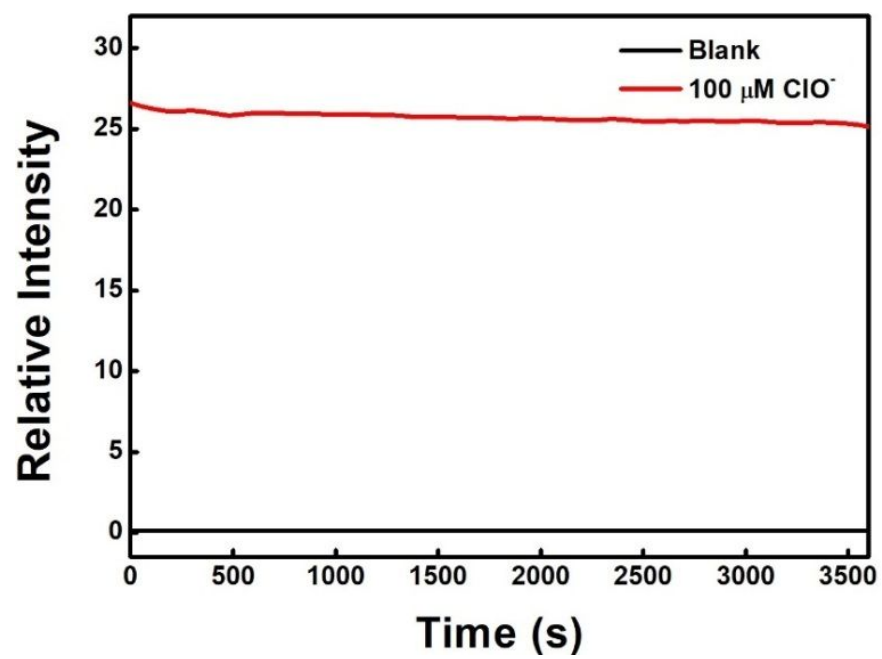

Figure S9. Dynamic emission intensity of PDC $(10 \mu \mathrm{M})$ with or without $\mathrm{ClO}^{-}(100 \mu \mathrm{M}) . \lambda_{\mathrm{ex}}=$ $400 \mathrm{~nm} . \lambda_{\mathrm{em}}=503 \mathrm{~nm}$.

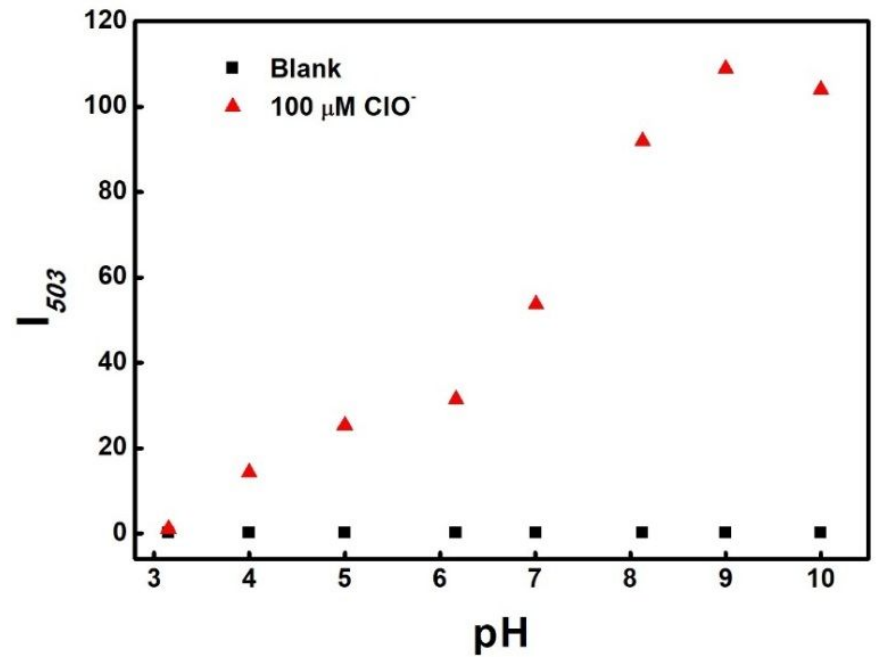

Figure S10. Fluorescence emission intensity $\left(I_{503}\right)$ of PDC $(10 \mu \mathrm{M})$ in presence or absence of $\mathrm{ClO}^{-}(100 \mu \mathrm{M})$ in B-R buffer solutions with different $\mathrm{pH}$ values. 


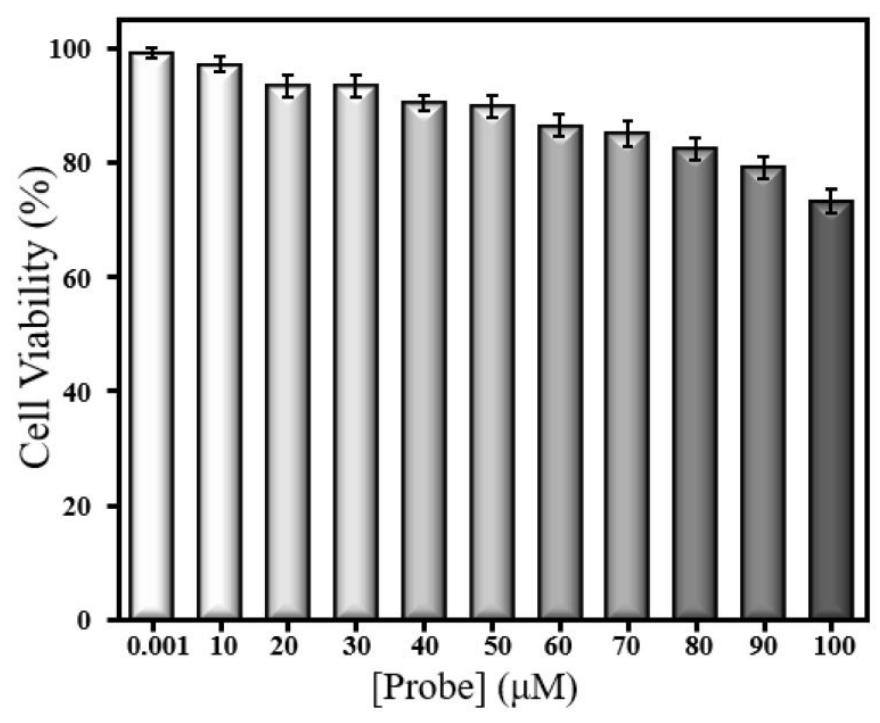

Figure S11. Cytotoxicity of probe PDC. RAW264.7 cells were incubated with PDC $(0-100 \mu \mathrm{M})$ for $24 \mathrm{~h}$. Results are mean $\pm \mathrm{SD}, \mathrm{n}=3$.

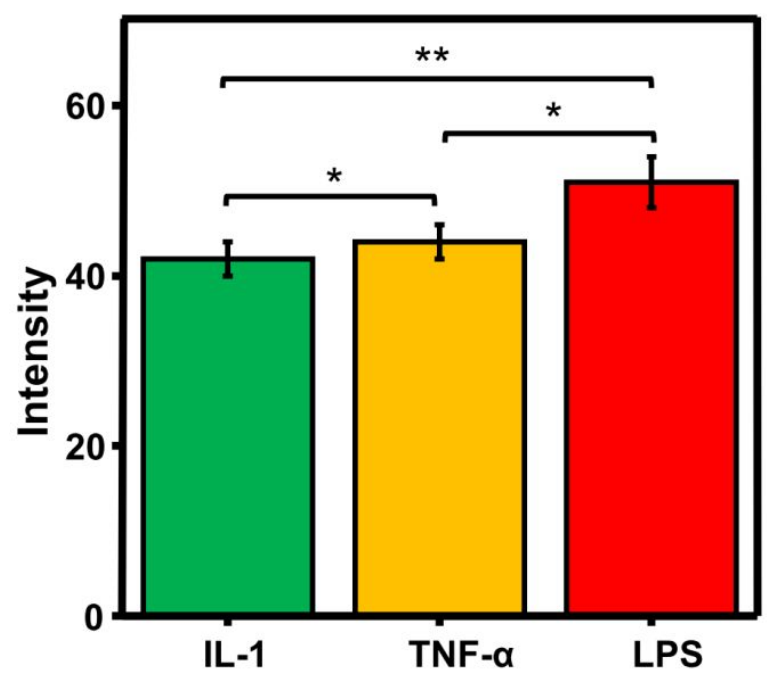

Figure S12. The difference between fluorescence intensity from LPS, TNF- $\alpha$ or IL-1 groups at $90 \mathrm{~min}$. Statistical analysis was performed using Student's t-test $(\mathrm{n}=3)$. $* * \mathrm{P}<0.01, * \mathrm{P}<0.05$, error bars are $\pm \mathrm{SD}$. 

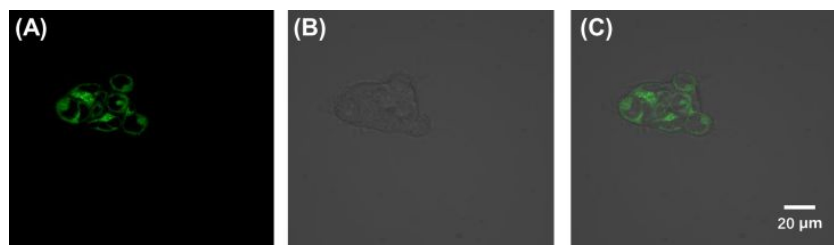

Figure S13. The probe $(10 \mu \mathrm{M})$ pre-treated Raw 264.7 cells were incubated with LPS (1 $\mu \mathrm{g} / \mathrm{mL}$ ) for $60 \mathrm{~min}$. (A) Fluorescence image; (B) bright image; (C) merged image of A and B. Scale bar: $20 \mu \mathrm{m}$.

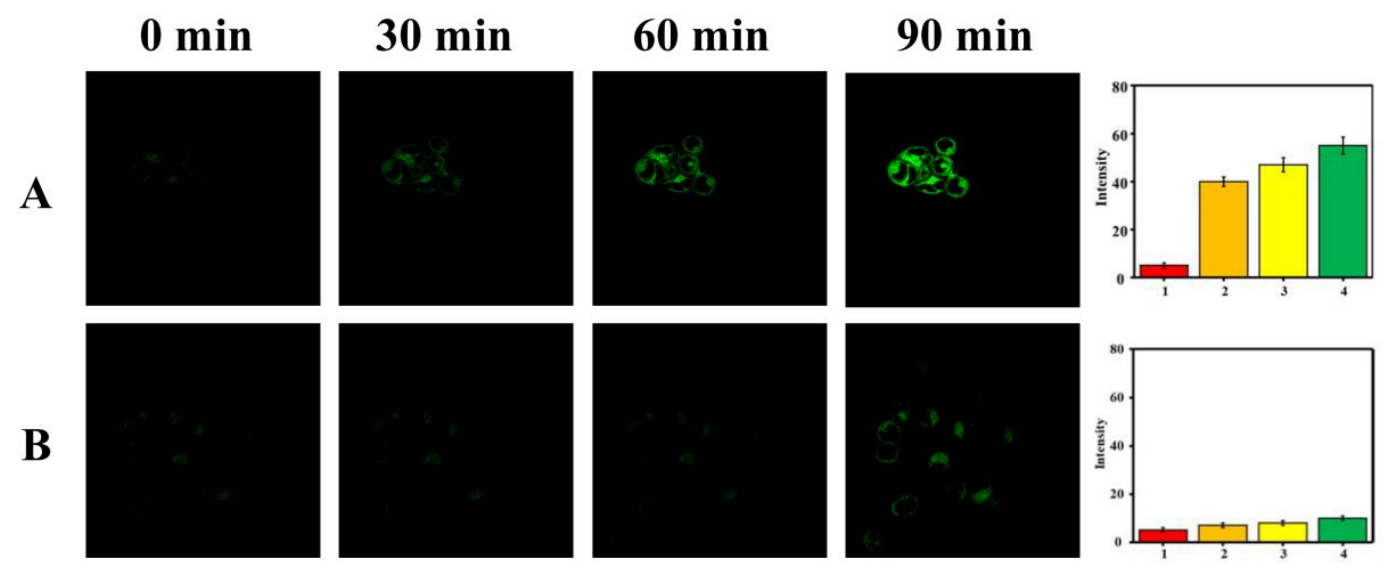

Figure S14. (A) The probe $(10 \mu \mathrm{M})$ pre-treated Raw 264.7 cells were incubated with LPS $(1 \mu \mathrm{g} / \mathrm{mL}$ ) for $0,30 \mathrm{~min}, 60 \mathrm{~min}$, and $90 \mathrm{~min}$. (B) The probe pre-treated Raw 264.7 cells were incubated with $\mathrm{ABAH}(400 \mu \mathrm{M})$ for $2 \mathrm{~h}$, and then incubated with LPS $(1 \mu \mathrm{g} / \mathrm{mL})$ for $0,30 \mathrm{~min}, 60 \mathrm{~min}$, and $90 \mathrm{~min}$. 
${ }^{1} \mathrm{H}-\mathrm{NMR}$ Spectrum of $\mathbf{2}$ in DMSO- $d_{6}(600 \mathrm{MHz})$ :

总

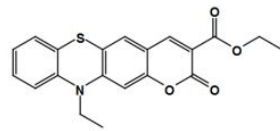

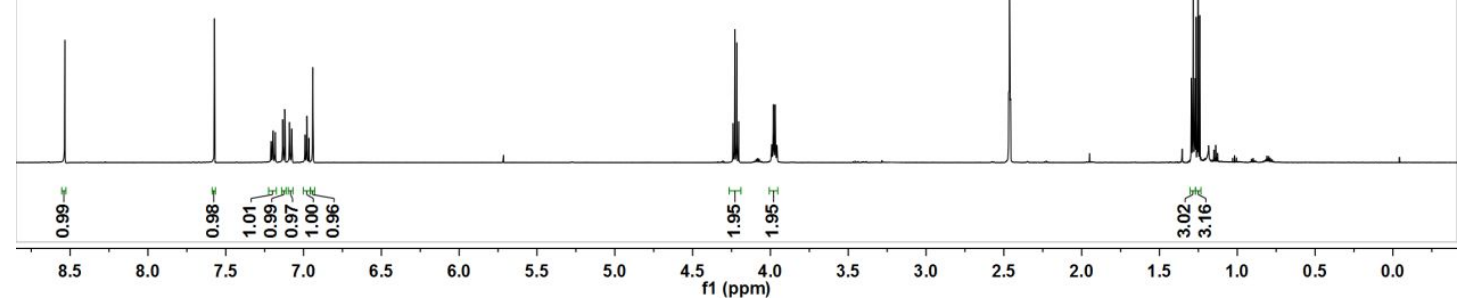

${ }^{1} \mathrm{H}-\mathrm{NMR}$ Spectrum of PDC in DMSO- $d_{6}(600 \mathrm{MHz})$ :

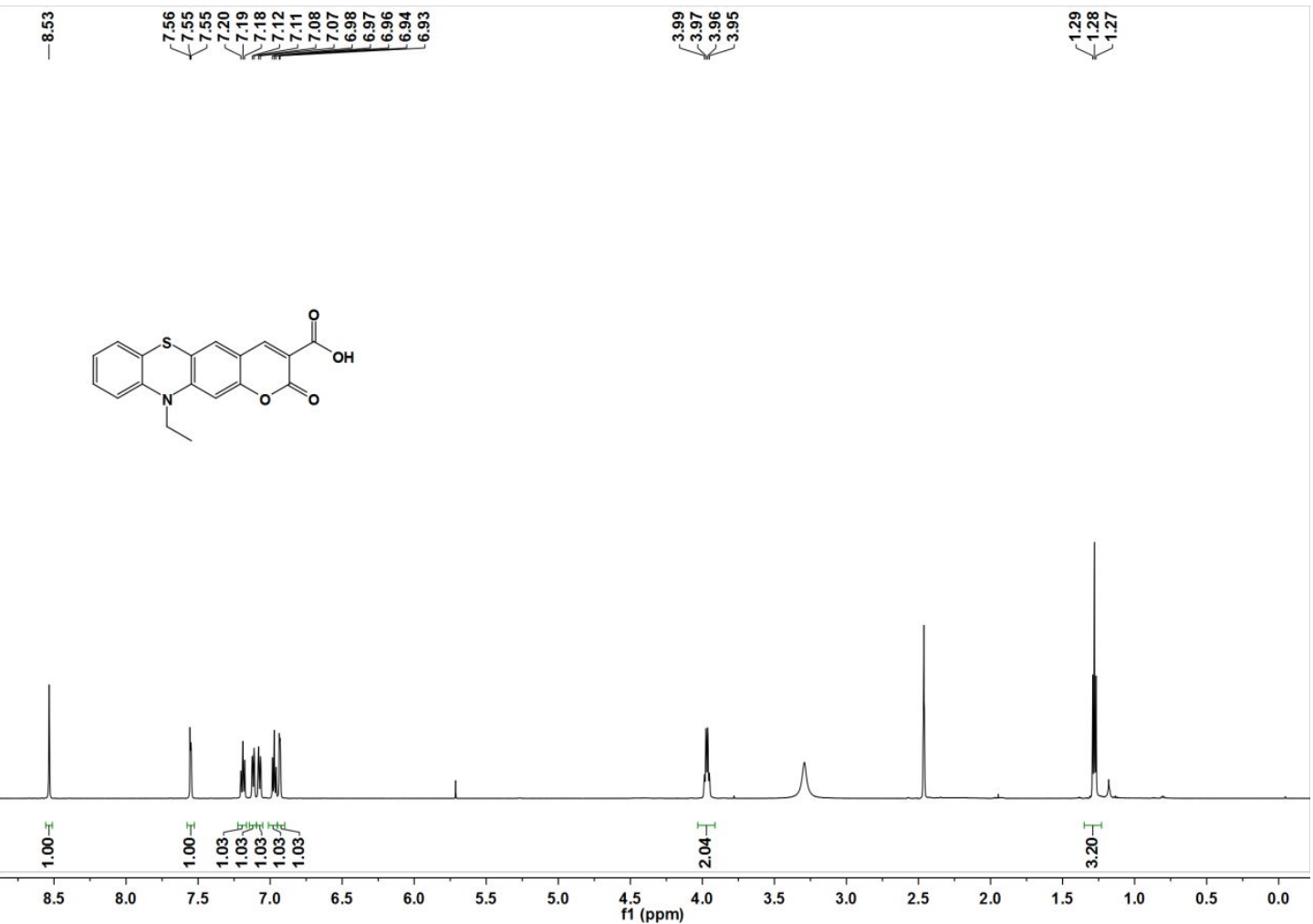


${ }^{13} \mathrm{C}-\mathrm{NMR}$ Spectrum of PDC in DMSO- $d_{6}(150 \mathrm{MHz})$

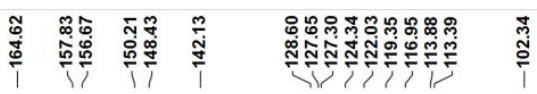

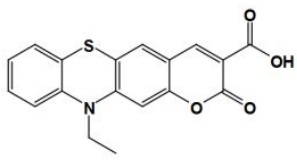

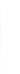
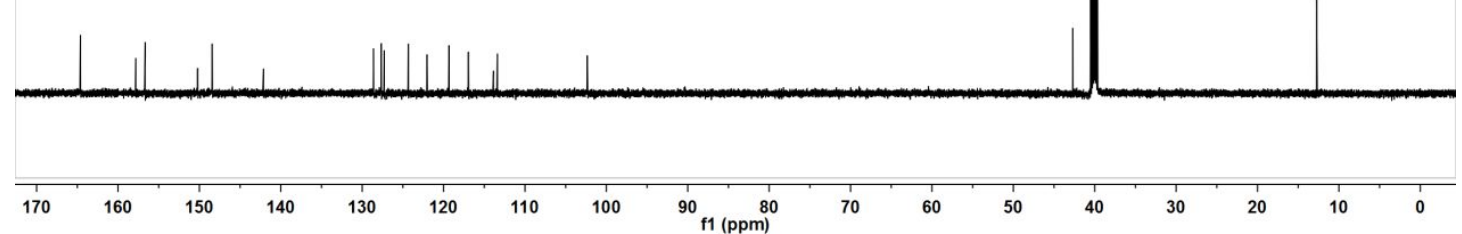

${ }^{1} \mathrm{H}-\mathrm{NMR}$ Spectrum of 3 in DMSO- $d_{6}(600 \mathrm{MHz})$ :
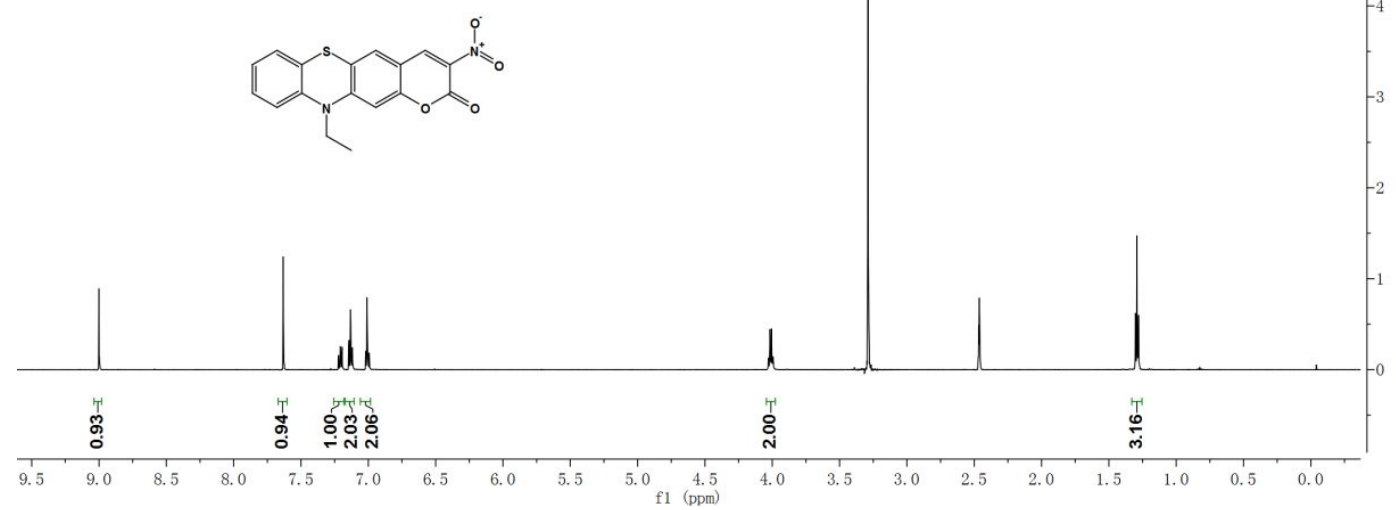
${ }^{13} \mathrm{C}-\mathrm{NMR}$ Spectrum of 3 in DMSO- $d_{6}(150 \mathrm{MHz})$

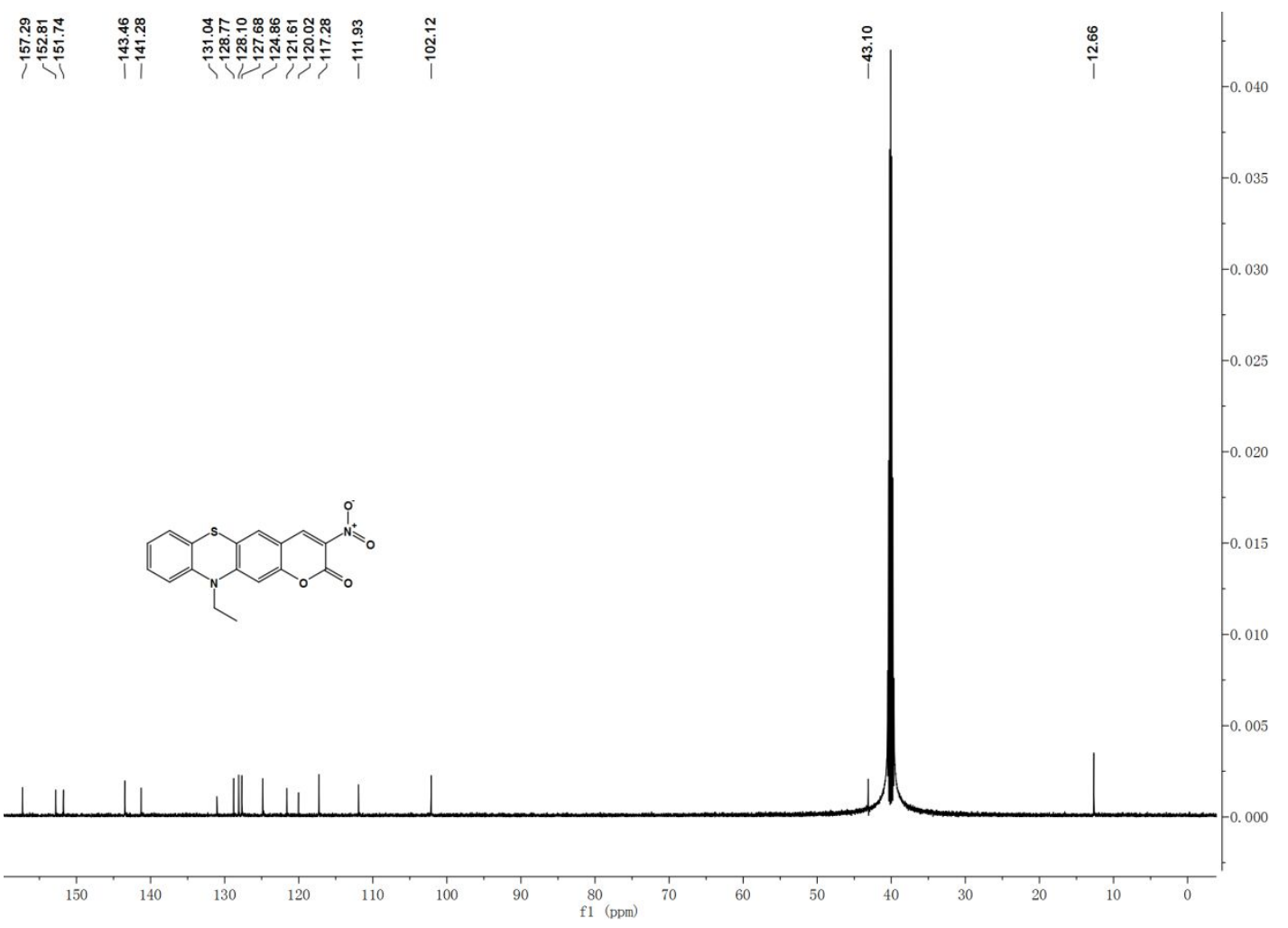

${ }^{1} \mathrm{H}-\mathrm{NMR}$ Spectrum of PDN in $\mathrm{CDCl}_{3}(600 \mathrm{MHz})$ :

等
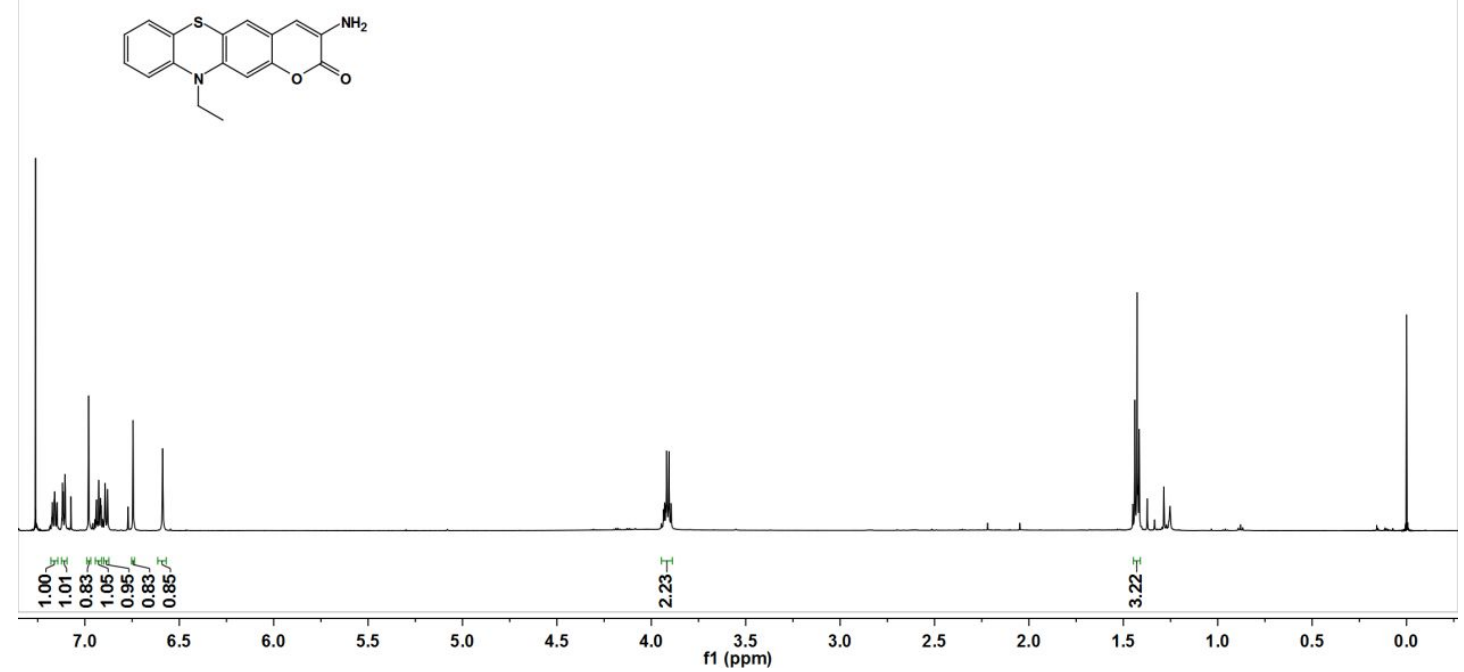
${ }^{13} \mathrm{C}-\mathrm{NMR}$ Spectrum of $\mathbf{P D N}$ in $\mathrm{CDCl}_{3}(150 \mathrm{MHz})$ :

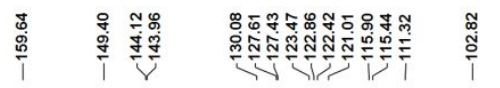

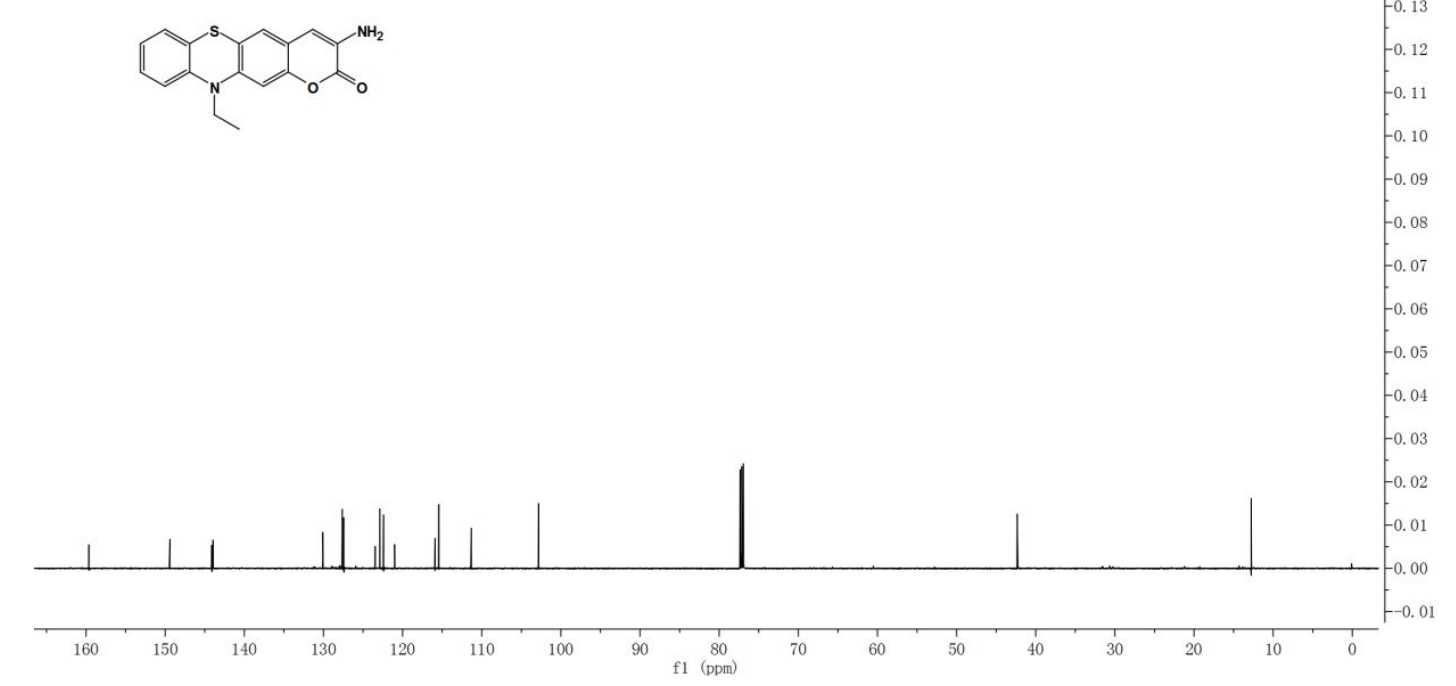

${ }^{1} \mathrm{H}-\mathrm{NMR}$ Spectrum of PDC-O in DMSO- $d_{6}(600 \mathrm{MHz})$ :

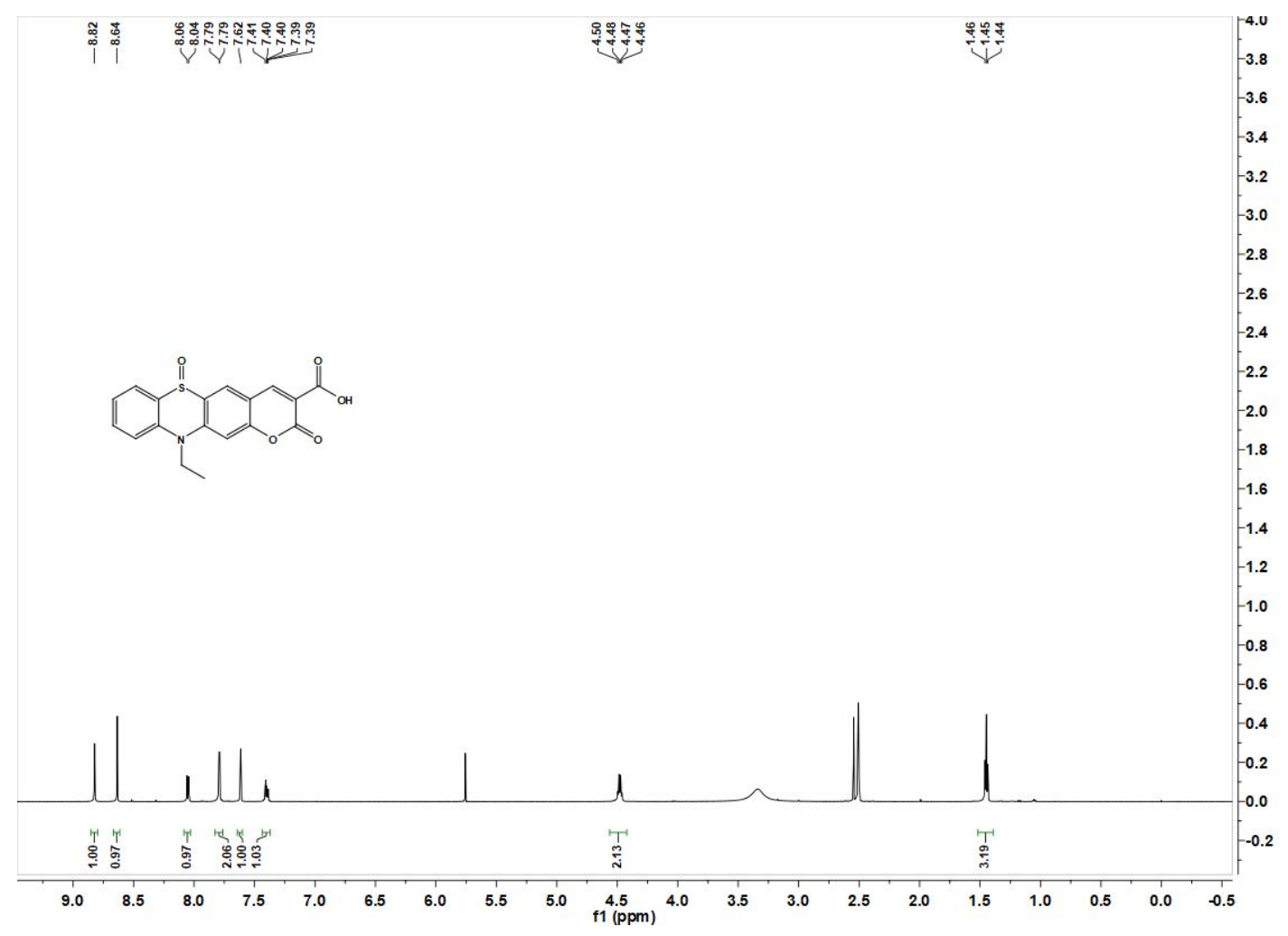


${ }^{13} \mathrm{C}-\mathrm{NMR}$ Spectrum of PDC-O in DMSO- $d_{6}(150 \mathrm{MHz})$

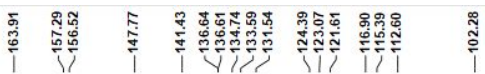
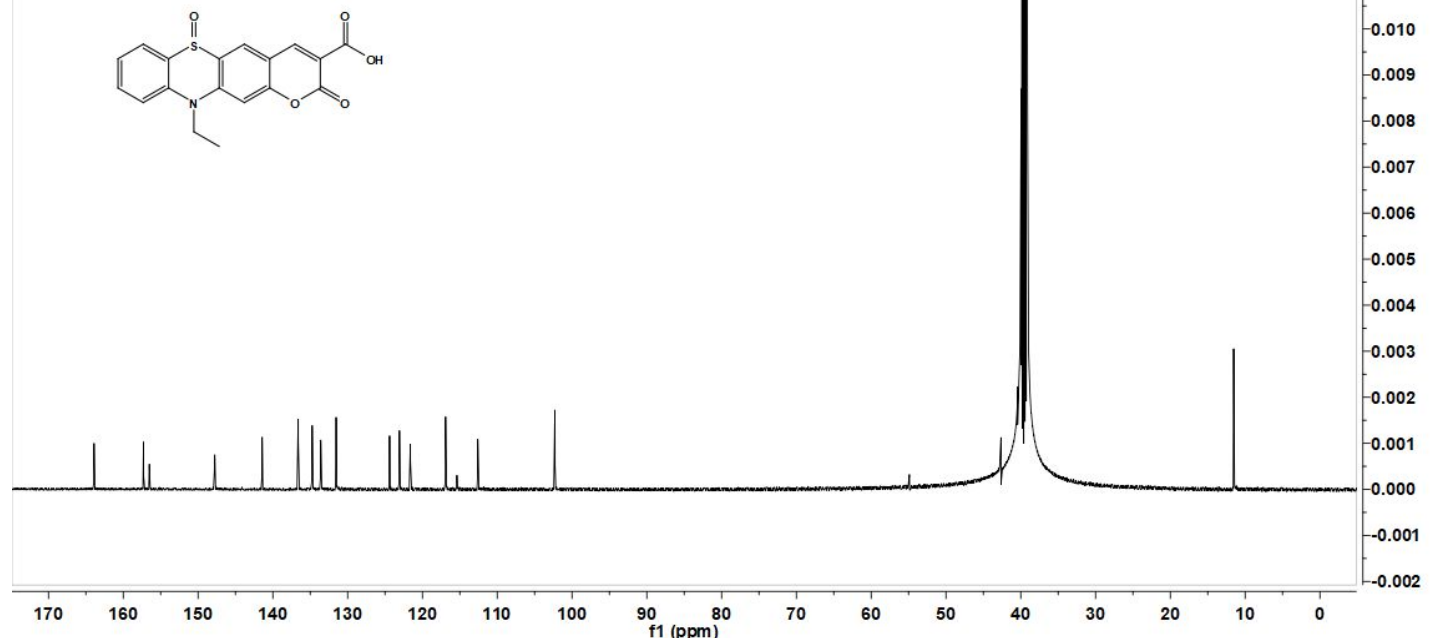

HRMS spectra of PDC:

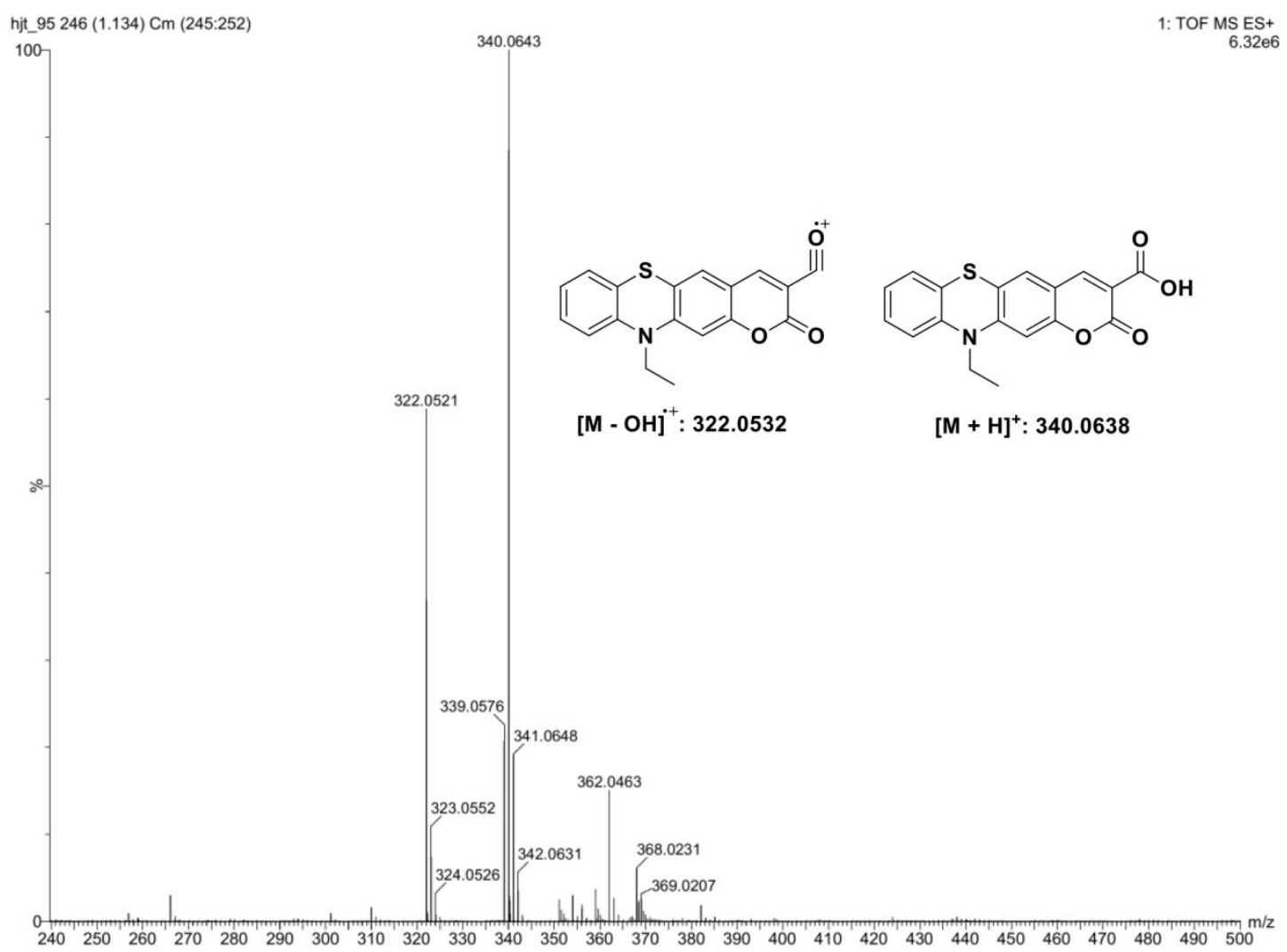


HRMS spectra of PDN:

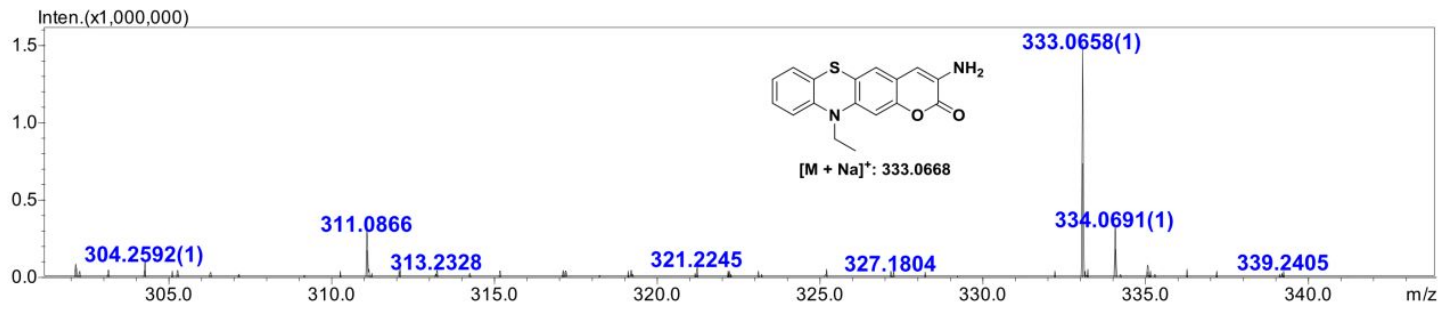

HRMS spectra of PDC-O:

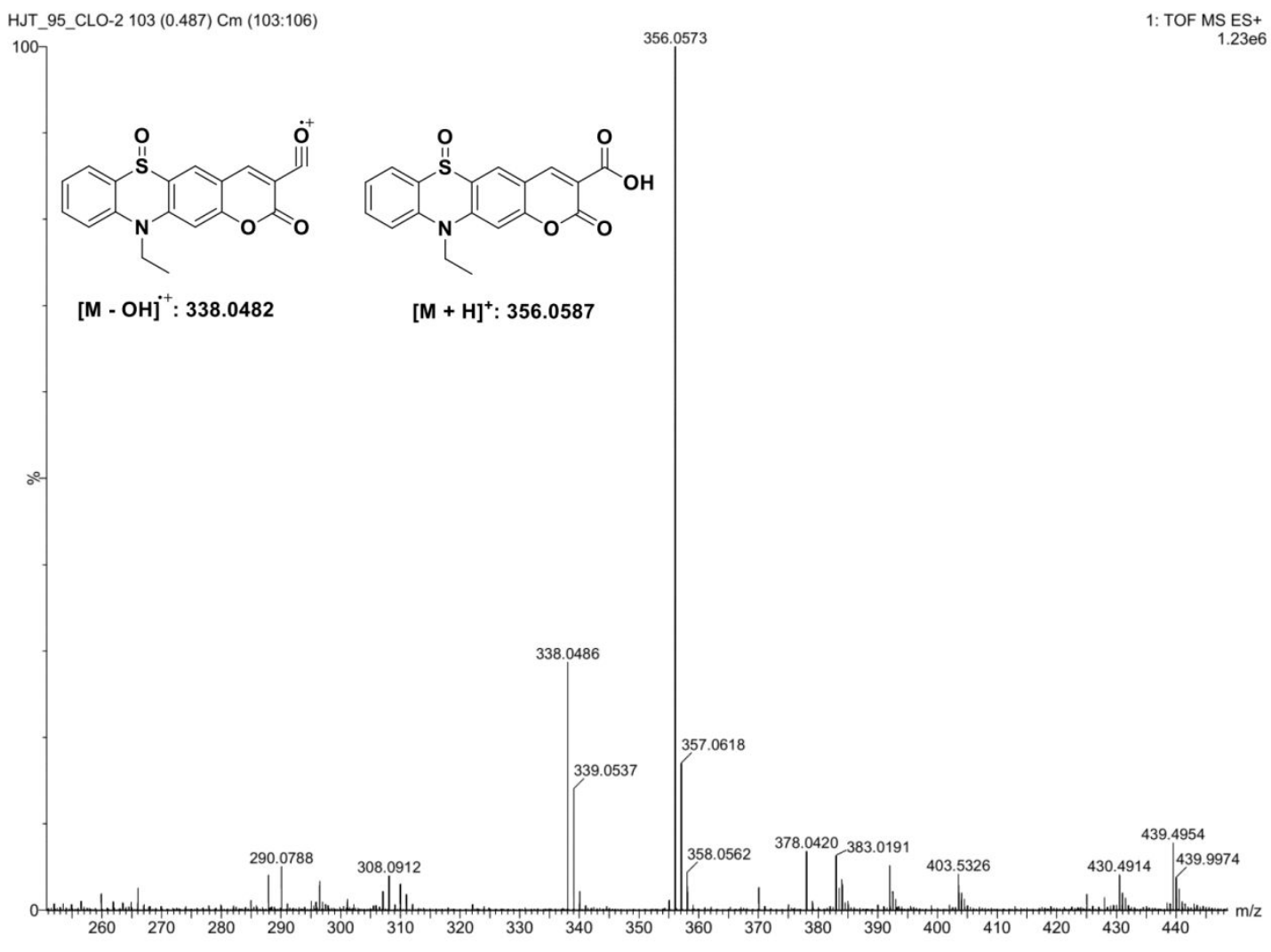

